\title{
A kultúra és a kommunikáció járványtani modellje
}

Dan Sperber: A kultúra magyarázata. Naturalista megközelítés

$\mathbf{M}$

Á

C

I

Ó

S

$\mathbf{T}$

Á

$\mathbf{R}$

S

A

D

Így hivatkozzon erre a cikkre:

Tófalvy Tamás. „A kultúra és a kommunikáció járványtani modellje”.

Információs Társadalom II, 2. szám (2002): 97-101.

= https://dx.doi.org/10.22503/inftars.II.2002.2.7

A folyóiratban közölt müvek

a Creative Commons Nevezd meg! - Ne add el! - Így add tovább! 4.0

Nemzetközi Licenc feltételeinek megfelelően használhatók. 


\title{
A kultúra és a kommunikáció járványtani modellje
}

\author{
Dan Sperber: A kultúra magyarázata. Naturalista megközelítés
}

Dan Sperber könyve, a Kultúra magyarázata, hat esszé hol lazább, hol szorosabb füzére, mintegy illusztrálva a szerzô azon megállapítását, miszerint a kultúra járványtani modellje nem egyetlen „nagy” elméletet kíván adni, hanem csupán egy egységes módszertant, ami alapján a kultúrák összessége értelmezhető. Ebből kiindulva Sperber nem a különbözó kommunikációs közegeket, hanem magukat a folyamatokat vizsgálja - így az Internet - és mobilkommunikáció epidemológiai leírása az „alaposabb” értelmezôk feladata lesz majd. A következőkben először bemutatnám magát a modellt, és végül sort kerítenék néhány olyan területre, ahol termékenyen hathatnak a sperberi gondolatok.

Nem lehet nem ejteni gyorsan pár szót a könyv címéről: Sperber nagy felelősséget vállalna magára ezzel, ha az ilyen direkt megközelítés nem lenne szinte hagyomány a kortárs angolszász - természetesen nem a nemzetiség, hanem a gondolkodásmód értelmében, lévén szerzốnk francia - elmélkedôknél. Ennek alapján úgy tûnhet, a tizenkilencedik-huszadik század fordulójának fizikájához hasonlatosan a mostani századfordulón a társadalom- és humán tudományok problémái oldódtak meg: a tudat magyarázata (Dennett, 1991) után végre itt van a kultúra magyarázata is. De szerencsére most - mint ahogy akkor sem volt - nem erról van szó.

Az alcímről annyit érdemes elmondani, hogy Sperber nem a „klasszikus” értelemben veszi és használja a kifejezést - a naturalizáció nála nem egy bizonyos fajta redukciót, hanem folytonosságot jelöl, saját szavaival: „Az a naturalizmus jár a fejemben, amely szeretné áthidalni a korlátokat a tudományok között, s nem egyetemes redukcióra törekszik.”(Sperber, 2001:138.)

De melyek azok a tudományok, amelyek között Sperber meg kívánja teremteni az átjárhatóságot? Ennek megválaszolására két lépcsőben érdemes áttekinteni a könyvet, először egyenként az önálló tanulmányként is megálló (és megjelent) fejezeteket, majd pedig együttesen, nagyjából követve is ezzel a kötet szerkezetét, szemrevételezve a levont és levonható konklúziókat és fóbb elméleti alapvetéseket.

Az elsố fejezet, a Hogyan legyünk igaz materialisták a antropológiában? az antropológiai kifejezések és mindennapi gyakorlatok ontológiáját veszi górcsố alá. Olyan közismert és előszeretettel használt fogalmakon keresztül, mint a házasság vagy a mítosz azt mutatja be, hogy ezek a jelentések bár rendkívül homályosak, és tulajdonképpen meghatározhatatlan, mit fednek, mégis léteznek, mint reprezentációk, és az értelmezés teszi lehetôvé használatukat.

A kulturális reprezentációk értelmezése címú fejezet tovább bontja ezt a gondolatot: a mentális és nyilvános reprezentációkat nem érdemes a megszokott elkülönítéssel szemlélni - a reprezentációk ezen formái csak a használatban térnek el lényegesen, aszerint, hogy milyen módon és közegben terjednek és alakulnak; voltaképpen az a 
kultúra epidemológiájának az egyik alapkérdése. „Így értelmezve a kulturális reprezentációk az adott csoportban lakozó mentális és nyilvános reprezentációk halmazának véletlenszerû alhalmazát képezik." (Sperber, 2001:52) Sperber kiemeli, hogy - természetesen - a reprezentációk terjedése sohasem ugyanannak a reprezentációnak a replikálódását, hanem a különbözô változatainak a szétszóródását jelenti. Ennek a múködésnek az egyik alapfeltétele az értelmezés, ami nem csak a mindennapi életben, hanem a társadalomtudományokban, legjellemzőbben a kulturális antropológia eszköztárában is erôteljesen jelen van. „A reprezentációk tudományos vizsgálatában az interpretáció ugyanannyira elengedhetetlen, mint a köznapi életben.” ( Sperber, 2001:61).

Ezt szerzőnk - vérbeli antropológusként - etnográfiai példával, a txikao törzs couvade gyakorlatán keresztül mutatja be, jól szemléltetve, hogy a terepmunkát végzó megfigyelő csak átfordítással, saját értelmezéssel tudja reprezentálni a hiedelmeket és szokásrendszereket.

A kulturális reprezentációk magyarázatát tekintve „...négy magyarázó típust vagy szándékolt magyarázatot fogok elkülöníteni az antropológiában,(...) az általánosításokat, a strukturális magyarázatokat s a funkcionális magyarázatokat; s végül van egy ritkább magyarázattípus, melynek egy változatát védelmezem, ezek az epidemológiai modellek.” ( Sperber, 2001:63). Ebből kiindulva a felsorolt antropológiai eljárások alternatívájaként ismerteti Sperber az epidemológiai modellt: ez a kulturális reprezentációk oksági magyarázatának egy továbbfejlesztett változata, melyben az egyik fő törvény(szerűsége)t a relevancia adja, (Sperber-Wilson, 1986) ami nem más, mint a hatás-erôfeszítés arány optimalizálása, amely a reprezentációkat afelé alakítja, hogy a saját kulturális kontextusukban a lehető legjobb hatékonysággal múködjenek.

A másik alapelv pedig - ami már tovább is visz minket a következő fejezethez az, hogy a kultúra magyarázata „nem valamiféle átfogó mechanizmusban keresendő, hanem számtalan mikromechanizmus együttes hatásában." (Sperber, 2001:79) Ennek a kimondásával Sperber azzal a „fanyalgó” társadalomtudományi diskurzussal helyezkedik szembe, ami tagadja a társadalmi gyakorlatok lélektani relevanciáját, annak ellenére, hogy a szociális közeg pszichikumokból épül fel.

A keresett tudományágak tehát nagyrészt megvannak már - egyfelôl a pszichológia és az ökológia együttes értelmezése az, ami a kultúra epidemológiája felé visz minket, másfelool pedig - a reprezentációfogalom új felfogásának közvetítésével - az antropológia és a kognitív tudomány házassága.

Az antropológia és a pszichológia: A reprezentációk epidemológiájának kérdése, és a $A$ hiedelmek epidemológiája címú fejezetek ezt a már konkretizálódott programot és elképzelést fejtik ki részletesebben. A legfontosabb megállapítások, amelyeket szerzônk az epidemológia evolúciós interpretációjában tesz, a hajlam és az érzékenység, az alapfogalmak és kulturális reprezentációk elkülönítése. „A hajlamok a biológiai evolúció folyamata során pozitív szelekció eredményeként jöttek létre, az érzékenységek viszont a hajlamok melléktermékei." (Sperber, 2001:95) Ez kulturális kontextusban azt jelenti, hogy az embergyermekeknek veleszületett hajlamuk van arra, hogy taxonomikus vagy funkcionális értelmezô sémák szerint alkossanak fogalmakat, és amelyek, ezek közül, nem dekomponálhatók (és figyelemfelkeltôk, és általában gyakoriak), azokat nevezhetjük alapvető fogalmaknak. A kulturális reprezentációk kialakulásában Sperber nagy jelentôséget tulajdonít a metareprezentációs képességünknek, amely nagy szerepet játszik fogalmi készletünk kiteljesítésében, azaz a „félig megér- 
tett dolgok" mégis egészlegesként történő értelmezéséhez. Az intuitív hiedelmek veleszületett következtetési mechanizmus által nyernek igazságot. Sperber példájával: „amit a tanár mond, az igaz” és reflektív hiedelmek - ezeket fóleg a forrásuk után racionalizáljuk, folytatva a példát: a „tanár azt mondja, hogy vannak női és hím növények" - elkülönítése azt a célt szolgálja, hogy megkülönböztetésük által nyilvánvalóvá váljon: teljesen eltérố mentális állapotok is eredményezhetnek azonos típusúnak tűnő hiedelmeket, amelyek azonban az eltérő kultúrákban teljesen másképpen múködnek, eltérố hiedelem- és vallási rendszereket építve fel.

Az utolsó két fejezet a Kiválasztás és vonzás a kulturális evolúcióban és A mentális modularitás és a kulturális sokféleség Sperber szerint (is) „ambiciózusabb és talán nehezebb”, mint az eddigiek. A kettő közül az elsőben Sperber a kulturális hagyományozódás, illetve a kulturális reprezentációk szelekciós modelljével - például Richard Dawkins mém-elméletével (Dawkins, 1986, 1990; Pléh, 2000) - helyezkedik szembe, mindvégig hangsúlyozva azonban, hogy ez nem a kulturális evolúció tényének semmibevételét, hanem éppen hogy a darwini tanok helyesebb értelmezését jelenti.

A szelekciós modell egy esetleges alternatívája lehet a befolyás-modell, azonban ezt sem tartva elégségesnek, Sperber ismerteti attrakciós modelljét, amirôl azt érdemes tudnunk, hogy nem oksági magyarázat, hanem statisztikai modell. Azokat a mintázatokat és szabályszerúségeket dokumentálja, amelyek egy bizonyos kulturális egység terjedése során létrejöhetnek. A magyarázatot a pszichológiai és ökológiai szinten kell keresni. Ezen a szinten pedig ismét csak a relevancia fogalma (és egyszerre gyakorlata) lesz az, ami meghatározza a reprezentációk epidemológiáját.

A kultúra és a modularitás viszonylatában Sperber azt szeretné bebizonyítani, hogy a modularitás nem rés, hanem erős bástya a kulturális sokféleség vonalán. Így egyszerre Fodorra támaszkodva és vele polemizálva síkra száll a Fodor által „tébolyult modularitásnak" titulált felfogás nem is annyira tébolyult felfogása mellett, miszerint a gondolkodási folyamatok is lehetnek modulárisak. (Fodor eredeti koncepciója a perceptuális folyamatokra vonatkozik.)

A gondolati folyamatok modularitása ellen két általánosan hangoztatott fő érv szól: ezek szerint, bár az észleletek lehetnek eltérőek, a fogalom mégis azonos lesz, azonkívül a kulturális sokféleség létezése eleve cáfolja az ilyenfajta modularitás lehetôségét.

Sperber azonban nem ért ezzel egyet: „Célom az, hogy megrendítsem ezt a köznapi felfogást és felvessem azt, hogy össze lehet kapcsolni a modularitást, a fogalmi integrációt, és a kulturális sokféleséget..." (Sperber, 2001:169) Felfogásában egy fogalom (valódi, illetve kulturális) alkot egy modult, és ezek a modulok úgy lépnek kölcsönhatásba egymással, hogy bizonyos jellegzetességeik átterjedhetnek más modulokra. A teljes magába zártság kevéssé jellemző tehát erre a kulturális modulfogalomra.

A kötet epilógusában (Követkestetések: mi is a tét?) szerzőnk bírálja a biológiai alapon rasszista, illetve a biologizmust rasszistának bélyegzố elméleteket, és azt a meglepó távlatot vázolja fel, miszerint lehetséges, hogy a jövóben a naiv és a tudományos fizika viszonyához hasonlóan a társadalomtudományok sem fognak a mindennapi társadalomértelmezésünkkel együtt élni.

Összegezve az eddigieket: Sperber gondolatmenete, illetve koncepciója talán két meghatározó tételból bontható ki a legvilágosabban. Az egyik tétel - vagy inkább törekvés - a reprezentáció egy olyan fogalmának a megalkotása, amely egyaránt használható a pszichológiai és társadalomtudományokban: 
„A kérdés most már az, hogy vajon újrafogalmazhatják-e a társadalomtudományok reprezentációfogalmukat a reprezentáció kognitív elgondolása segítségével. Megpróbálom megmutatni, hogyan lehet ezt megtenni, és ennek eredményeként hogyan tehetố feszesebbé a társadalomtudományok egész ontológiája, s hogyan válik elképzelhetôvé a társadalomtudományok egész programja." (Sperber, 2001:42).

Ez a program lenne a második tétel, a reprezentációk epidemológiája, ami Sperber szerint a kultúra lényegi változásait tárná fel: nem a reprezentációk tartalma, hanem inkább a reprezentációk terjedésének mintázatai azok, amik meghatározzák egy kultúra, tágabban $a$ kultúra lényegét. A tartalmak folyamatosan változnak, konstruálódnak, a terjedés vagy éppen eltűnés azonban szükségszerú. Erre a folyamatra viszont nem alkalmazhatóak a kulturális evolúcióelméletek szelekciós modelljei, ezzel együtt Darwin is megnyugodhat, mert legalapvetốbb meglátásai jobban hasznosulnak abban a kultúraértelmezésben, ahol „....a kulturális evolúciót a reprezentációk és produkciók, az átviteli folyamat során bekövetkezô, különbözô lehetséges átalakulásainak eltéréseiben található összegződő hatásaiból lehet levezetni."(Sperber, 2001:165).

A recenzensnek az internetes, kommunikáció viszonylatában azért is tûnik anynyira inspiratívnak az epidemológiai elvek megmérettetése, mert a világhálón történô kommunikatív aktusok és reprezentációs rendszerek különbözố múködései viszonylag jól körülhatárolhatók és definiálhatók. Ezalatt azt értem, hogy a másolás vs. értelmezés kontextusában az információk itt „szimultán” módon terjednek, egyszerre legalább két típusban: egyfelôl adottak a honlapok és grafikus információk azonos tartalmai, másfelól emellett megélnek a személyes értelmezések is.

Azonban vannak olyan formái az internetes illetve mobilkommunikációnak, amelyek meglepően kevéssé változtatják meg a „hagyományos” érintkezési módokat, és így a reprezentációk értelmezését és terjedését: akár chatelésrôl, e-mailezésról, vagy webkamerás kommunikációról van szó, a különbség csak annyi, hogy a teljes metakommunikációs és szociális kompetenciának csak egy bizonyos része kerül kiemelésre, illetve használatra.

Az igazi problémák, vagy változások ebben a közegben a reprezentációk terjedésének követhetetlensége folytán lépnek fel - ahogy azt mindennapi életünk során is sűrűn megtapasztalhatjuk. Az Interneten keresztül kiépített kapcsolatrendszerek térben szétszórtak és a legtöbbször ellenőrizhetetlenek, ennek ellenére (sốt, néha pont ezért) ez sem jelent feltétlenül jelentős változást a kiépíthető kapcsolatok számát tekintve - mármint a való élethez viszonyítva Dunbar (2002) . (Dunbar szerint biológiai evolúciónk során kialakult velünk született sajátosságunk, hogy maximum 100-150 emberrel tudunk számottevő intenzitású kapcsolatot tartani. Az államok létrejötte előtt ez határozta meg a csoportméret felső korlátját, nagyobb szerveződés esetén a törzsi-nemzetségi hierarchia egységeit. Lásd még Calvin ((1997) - a szerk.)

Végül még annyit érdemes megjegyezni, hogy meglehet, a szerző hibája, hogy az egyszeri olvasó igen keveset tudott meg a metafora „valódi” alapját képező orvosi járványtanról, és arról, hogy van-e egyáltalán gyakorlati relevanciája ennek a párhuzamnak. (Van: Boyd és Richerson a modell segítségével kulturális jelenségek terjedését járványtani matematikai eszközökkel modellezi. (Boyd, R. \& Richerson, P. (1985) - a szerk.)

De azért nem kell megijedni: a kultúra egyáltalán nem kóros - csak kórosan ragályos. 
Sperber, Dan, (2001): Explaining Culture: a Naturalistic Approach. (A kultúra magyaráæata, Pléh Csaba fordítása, Osiris Kiadó

$$
\text { Tófalvy Tamás }
$$

\section{IRODALOM}

Boyd, R.\& Richerson, P., (1985): Culture and the Evolutionary Process University of Chicago Press

Calvin, W., (1997): A gondolkodó agy. Budapest, Kulturtrade

Dawkins, R., (1986): Az önzố gén. Budapest, Gondolat.

Dawkins, R., (1990): A hódító gén. Budapest, Akadémiai.

Dennett, Daniel G., (1991): Consciousness Explained. Little Brown, Boston.

Dunbar, R., (2002): Are There Cognitive Constraints on an E-world? Előadás, New Perspectives on 21st Century Communications, MTA

Pléh Cs., (2000): A gondolatok terjedési mechanizmusai: mémek vagy fertözések. In: Replika 40.

Sperber, D. \& Wilson, D., (1986): Relevance: Communication and Cognition. Oxford, Blackwell.

A szerzôtől további szövegek és információk megtalálhatók a saját honlapján:

www.dan.sperber.com. 